Submitted to Tectonophysics (10 March 2007)

Re-submitted (11 May 2007)

\title{
Variable microstructure of peridotite samples from the southern Mariana Trench: evidence of a complex tectonic evolution
}

\author{
Katsuyoshi Michibayashi ${ }^{1, *}$, Miki Tasaka ${ }^{2}$, Yasuhiko Ohara ${ }^{3}$, Teruaki Ishii ${ }^{4}$, Atsushi \\ Okamoto $^{5}$, Patricia Fryer ${ }^{6}$ \\ IInstitute of Geosciences, Shizuoka University, Shizuoka, Japan \\ ${ }^{2}$ Department of Earth and Planetary Sciences, University of Tokyo, Tokyo, Jap an \\ ${ }^{3}$ Ocean Research Laboratory, Hydrographic and Oceanographic Department of Japan, Tokyo, Japan \\ also at Institute for Research on Earth Evolution, Japan Agency for Marine-Earth Science and Tec hno bgy, \\ Kanagawa, Japan \\ ${ }^{4}$ Ocean Research Institute, University of Tokyo, Tokyo, Jap an \\ now at Institute for Research on Earth Evolution, Japan Agency for Marine-Earth Science and Technology, \\ Kanagawa, Japan \\ and also at Fukada Geological Institute, Tokyo, Japan \\ ${ }^{5}$ Grad uate School of Environmental Studies, To hoku University, Send ai, Japan \\ ${ }^{6}$ SOEST, University of Hawaii at Manoa, Honolulu, Hawaii, USA \\ * Corresponding author. Tel: +81 54 2384788; fax: +81 542380491 \\ E-mail address: sekmich@ipc.shizuoka.ac.jp (K. Michibay ashi)
}




\section{ABSTRACT}

25

We retrieved samples of peridotite from a dredge haul (KH92-1-D2) collected during Cruise KH92-1 undertaken by the research vessel (R/V) Hakuho in 1992 at the landward trench slope of the southern Mariana Trench $\left(11^{\circ} 41.16^{\prime} \mathrm{N}, 143^{\circ} 29.62^{\prime} \mathrm{E}\right.$; depth 6594-7431 m), which is the deepest ocean in the world. Ten of 30 retrieved samples possessed both a foliation and lineation, as assessed from 46 thin sections of various orientations and observations of hand samples. The samples showed marked variation in microstructure, ranging from coarse $(>5 \mathrm{~mm})$ equigranular and intensely elongated textures to finer $(<1 \mathrm{~mm})$ porphyroclastic and fine-grained equigranular textures. Olivine fabrics also varied among the different samples, with (010)[100] and (010)[001] patterns (termed A- and B-type, respectively) observed in samples with coarse textures and no clear patterns observed in samples with fine textures. Even though the peridotite samples were retrieved from a single dredge site, some contain primary tectonic microstructures and some contain secondary microstructures. Recent bathymetric and topographic analyses indicate that the lithosphere in this region is as thin as $20 \mathrm{~km}$. Such a thin lithosphere may have been intensely deformed, even perhaps in the ductile regime, during fore-arc extension; consequently, the observed variations in microstructure within the peridotite samples probably reflect the complex tectonic evolution of the southern Mariana region.

44 Keywords: mantle wedge, crystal-preferred orientation, olivine, Mariana Trench, subduction, 45 slab tear, microstructure, Challenger Deep 


\section{Introduction}

The Mariana Trench marks the location at which the Pacific plate subducts beneath the eastern edge of the Philippine Sea plate (Fig. 1A). The Challenger Deep, part of the southern Mariana Trench southwest of Guam, is the deepest oceanic trench in the world, and is up to $2 \mathrm{~km}$ deeper than the average depth along the axis of the Mariana Trench (Fujioka et al., 2002; Fryer et al., 2003; Gvirtzman and Stern, 2004). The strike of the trench changes from north-south in the northern section to east-west in the south (Fig. 1A). The fore-arc narrows southward and the trench-arc distance decreases until a point near the island of Guam where the Mariana Ridge comes within about $150 \mathrm{~km}$ of the Mariana Trench (Fig. 1A).

The southern Mariana Trench appears to be associated with active steepening of the subducting slab along a zone of weak coupling with the overriding plate related to tearing of the slab (Fryer et al., 2003; Gvirtzman and Stern, 2004). From north to south along the trench, the position of the asthenospheric wedge between the subducting and overriding plates progressively moves upward and trenchward; the wedge appears to be extremely shallow in the southern part of the trench ( $\leq 20 \mathrm{~km}$; Fig. 1B; Gvirtzman and Stern, 2004).

The Mariana Trench lacks an accreted sedimentary prism (Ishii, 1985; Bloomer and Fisher, 1987) and consists mainly of mafic and ultramafic igneous rocks that are typical of island arc ophiolites (Natland and Tarney, 1982). Serpentinized peridotites have been dred ged, drilled, and sampled by submersibles at several localities on the landward slopes of the trench (Dietrich et al., 1978; Bloomer, 1983; Fryer, 1992; Ishii et al., 1992, Ohara and Ishii, 1998). These peridotites have mostly been studied in terms of their petrological features. Although the active tectonics of the area in which the peridotites occur, along the southern and deepest part of the Mariana Trench, has been recently considered (e.g., Fujioka et al., 2002; Fryer et al., 2003; Gvirtzman and Stern, 2004), the structural characteristics of the peridotites remain ambiguous. In the present paper, we demonstrate that the peridotite samples record contrasting microstructures, ranging from coarse-grained to fine-grained textures and a wide range of olivine fabrics, and that this variation possibly reflects dynamic processes within the southern Mariana region.

\section{Dredge sampling and sample preparation}

Peridotite samples analysed in this study were retrieved in 1992 from a dredge haul (KH92-1-D2) collected by the University of Tokyo research vessel Hakuho (now operated by the Japan Agency for Marine-Earth Science and Technology) during Cruise KH92-1 over the 
landward Mariana Trench slope at $11.5^{\circ} \mathrm{N}$, adjacent to the Challenger Deep (Fig. 1 A; Ishii et al., 1993; Ohara and Ishii, 1998). The dredge haul recovered more than 500 ophiolitic samples (280 $\mathrm{kg}$ in total weight), including serpentinized peridotite, pyroxenite, and various metamorphic rocks. The samples are angular, $1-50 \mathrm{~cm}$ in diameter, and have a thin coating of Mn-oxide. The samples appear to be derived from large talus ramps fed from outcrops on the inner trench slope, rather than from diapiric serpentinite seamounts (Ohara and Ishii, 1998).

We selected 30 samples for analysis; all samples were larger than $10 \mathrm{~cm}$ across with less serpentine. As our strategy involved microstructural and fabric analyses as a means of obtaining information about dynamic process with in the mantle wedge, it was very important to identify foliation and lineation within the rock samples. The peridotite samples are dunites, meaning that the foliation and lineation within these samples are defined solely by the alignment of spinel grains (e.g., Nicolas and Poirier, 1978; Michibayashi et al., 2000). As it proved difficult to identify structures with the naked eye, we analysed saw-cut samples in the laboratory and thin sections cut at various orientations. We identified both foliation and lineation in 10 of the 30 samples, as assessed from 46 thin sections and observations of hand samples.

\section{Microstructures}

Three samples exhibit coarse equigranular textures (e.g., Fig. 2A and B). The structures in these samples are weakly developed, and analyses of several thin sections were required to identify the foliation and lineation in each case. Olivine grains vary in size from 2 to $6 \mathrm{~mm}$. Although grain boundaries are commonly obscured by serpentinization, relatively unaltered areas reveal triple junction geometries. Locally, grains are weakly elongated and show undulose extinction, with minor patches of grain-size reduction up to $100 \mu \mathrm{m}$ across.

Two samples possess elongate olivine textures (Fig. $2 \mathrm{C}$ and D). Coarse $(\leq 5 \mathrm{~mm}$ ) olivine grains are variably elongated with aspect ratios of up to 5:1. The long axes of the elongate grains are aligned within the plane of the foliation; this preferred orientation reflects slip along cleavage planes or kinking within grains with patchy extinction or moderately undulose extinction. Rare patches of fine-grained $(\leq 100 \mu \mathrm{m})$ dynamically recrystallized grains occur along the boundaries between highly elongate grains. These features appear to indicate deformation under conditions of low-temperature plasticity.

The remaining five foliated samples exhibit either porphyroclastic textures or fine-grained equigranular textures. The porphyroclastic textures are variable in character (e.g., 
112 Fig. 2E): the shapes of porphyroclasts range from round to elongate (with aspect ratios of up

113 to $3: 1$ ), resulting from slip along cleavage planes, and the grain sizes of neoblasts vary from $114 \sim 10$ to $200 \mu \mathrm{m}$. The effects of pervasive serpentinization mean that the detailed 115 microstructure of these samples is unclear. Low-temperature plastic deformation mechanisms 116 such as kinking appear to have been the primary agent of grain-size reduction. In con trast, the 117 fine-grained equigranular textures are homogeneous (e.g., Fig. 2F), with grain sizes of $\sim 200$ $118 \mu \mathrm{m}$. Grain boundaries show triple junction geometries. Relict porphyroclasts occur locally 119 and have irregular shapes, indicating dynamic recrystallization of the coarse primary grains.

\section{4. Fabric analysis}

122 To examine the deformation conditions in more detail, we used a scanning electron 123 microscope equipped with an electron-backscatter diffraction system (housed at the Center for 124 Instrumental Analysis, Shizuoka University, Japan; e.g., Michibayashi et al., 2006b) to 125 measure the crystal-preferred orientations (CPOs) of olivine from highly polished thin 126 sections. We measured the orientations of between 161 and 327 olivine crystals per sample 127 (Fig. 3) and visually checked the computerized indexing of the diffraction pattern for each 128 crystal orientation. As we are unable to measure strain from naturally deformed samples, the 129 fabric strength (i.e., J-index) is used to evaluate the intensity of the CPO (e.g., Ben Ismail and 130 Mainprice, 1998; Michibayashi and Mainprice, 2004; Michibayashi et al., 2006a; 131 Michibayashi et al., 2006b).

132 A (010)[100] CPO pattern, which is termed an A-type pattern (e.g., Jung et al., 133 2006), was observed in two samples: one with a coarse granular texture (Figs. 2A and 3A) 134 and another with an intensely elongated texture (Figs. $2 \mathrm{C}$ and $3 \mathrm{C}$ ). The sample with the 135 intensely elongated texture shows a greater degree of scatter in the obtained CPO pattern and 136 a lower J-index value (Fig. 2C) compared with the sample with coarse equigranular texture 137 (Fig. 3A). This may indicate that the CPO pattern was partly altered during retrogressive 138 deformation.

139 A (010)[001] CPO pattern, which is termed a B-type pattern (e.g., Jung et al., 2006), 140 was observed within two samples: one with coarse granular texture (Figs. 2B and 3B) and 141 another with intensely elongated texture (Figs. 2D and 3D). In both cases, the intensity of the 142 CPO is relatively weak: J-index values are less than 4 . In terms of the CPO pattern for the 143 sample with coarse equigranular texture, although the maximum densities of the three axes 144 are consistent with a B-type pattern, the [100] and [001] axes define a weak girdle subparallel 
145 to the foliation (Fig. 3B). The CPO pattern for the sample with intensely elongated texture

146 reveals scattered [100] axes, relatively concentrated [010] axes, and [001] axes that define a 147 weak girdle (Fig. 3D). As with the A-type pattern, these results may imply that the CPO 148 pattern was partly altered during retrogressive deformation.

149 Despite possessing well-defined foliations and lineations, the CPO patterns for 150 samples with porphyroclastic and fine-grained equigranular textures are too weak to reliably 151 identify A- or B-type patterns; J-index values for these samples are up to 4 (e.g., Fig. 3E and 152 F). These weak CPO patterns probably reflect the effects of low-temperature deformation 153 (e.g., Michibayashi and Mainprice, 2004; Michib ayashi et al., 2006a).

154

\section{$155 \quad 5$. Interp retation and discussion}

\section{5.1. Variable microstructures and fabrics along the southern Mariana Trench}

157 The peridotite samples obtained from the southern Mariana Trench record a wide 158 range of microstructures, varying from coarse-grained to fine-grained textures. In general, the 159 coarse-grained textures indicate high-temperature deformation at solidus or hyper-solidus 160 temperatures typical of as thenospheric flow; these are therefore interpreted as primary mantle 161 textures. In contrast, the fine-grained textures reflect ductile flow at relatively low 162 temperatures (Nicolas and Poirier, 1978). Accordingly, we classify the samples into two 163 categories: those with coarse equigranular textures (i.e., primary textures; Fig. 2A-D) and 164 those resulting from various degrees of deformation at relatively low temperatures (i.e., 165 late-stage modified textures; Fig. 2E-F). The former category can be further subdivided in to 166 two types based on CPO patterns: A-type (Fig. 3A and C) and B-type (Fig. 3B and D).

It is generally accepted that A-type patterns probably reflect primary asthenospheric 168 flow (i.e., high temperatures and low stress); however, the development of B-type patterns is 169 less certain, being variously ascribed to low temperatures, high degrees of stress, and/or high 170 water contents (e.g., Nicolas and Poirier, 1978; Jung and Karato, 2001; Jung et al., 2006; 171 Katayama and Karato, 2006). Given the uncertainty in the provenance and geographic 172 relationships among the samples described in the present study, it is difficult to explain the 173 contrasting fabrics obtained from a single dredge haul; nonetheless, our results indicate that 174 peridotite in the source region of the dredge site has been variably deformed and/or 175 recrystallized under a range of temperature, stress, and water fugacity conditions. Therefore, 176 while the peridotite samples were collected from a single dredge site, the rocks may have 177 been derived from significantly different geological settings. 
We now place our results in the context of regional tectonics by considering regional-scale analyses based on sidescan surveys and topographic and seismic studies (Fryer et al., 2003; Gvirtzman and Stern, 2004; Miller et al., 2006). Side-scan sonar data reveal numerous normal faults on the sea floor in the forearc west of Guam (Fryer et al., 2003). Moreover, the forearc immediately west of Guam is broken by two N-S striking left-lateral fault zones that each record approximately $20 \mathrm{~km}$ of displacement; these faults separate the Santa Rosa Bank from Guam (Fig. 1A). The sea floor west of the Santa Rosa Bank shows widespread deformation, including numerous faults of varying scales (Fryer et al., 2003). These bathymetric features suggest active tectonics in this region. of the Marina system would be required to separate the Santa Rosa Bank from the remnant arc of the West Mariana Ridge. Fryer et al. (2003) argued that north-south fore-arc deformation in this region resulted from slab rollback and trench retreat associated with a tear in the subducting plate. This proposal was supported by Gvirtzman and Stern (2004), who suggested 192 that the lithosphere within the Challenger Deep is as thin as $20 \mathrm{~km}$ (Fig. 1B). Such a thin 193 lithosphere could well have been intensely deformed, even in the ductile regime, during 194 forearc extension. This scenario is consistent with the wide range of microstructures observed 195 within the peridotite samples described in the present study.

5.2. Peridotites from the Southern Mariana Trench: a key to understanding the tectonics and 198 rheology of the fore-arc side of the Mariana mantle wedge

199 We demonstrated that the peridotite samples obtained from a dredge haul on the 200 landward trench slope of the southern Mariana Trench, which is the site of the deepest ocean 201 in the world, represent various components of the mantle wedge. As observed previously in 202 the southernmost Mariana Trench across the Challenger Deep, vertical and lateral thinning of 203 the overriding lithosphere leads to the upward and trenchward propagation of the 204 asthenosphere (Fig. 1B; Gvirtzman and Stern, 2004). Hence, one might argue that the 205 peridotites with primary textures were derived from the region of highly uplifted 206 as thenospheric mantle (Fig. 1B).

207 The peridotites analysed in the present study represent highly refractory residue 208 following extensive mantle melting (Ohara and Ishii, 1998; Michibayashi and Tasaka, 209 unpublished data). Dehydration of the subducting slab might lead to hydration of the uplifted 210 region of shallow asthenosphere (Fig. 1B; e.g., Iwamori, 1998), leading in turn to partial 
211 melting of the mantle wedge. The presence of arc volcanics across the entire width of the

212

213

214

215

216

217

218

219

220

221

222

223

224

225

226

227

228

229

230

231

232

233

234

235

236

237

238

239

240

241

242

243 southern Mariana system west of Guam (Fryer et al., 1998) is consistent with this hypothesis.

In summary, the variable microstructural features of the analyzed samples could well reflect the complex structural evolution of the southern Mariana region, where the trench extends across the forearc to the back-arc side of the Mariana arc system (Fig. 1A). Further detailed studies of peridotites sampled from the world's deepest ocean will reveal additional details of the regional tectonics, from the sea floor to the deep lithospheric mantle and as thenospheric mantle within the southern Mariana mantle wedge.

\section{Acknowledgements}

Construction of the figures that show CPO data and calculations of fabric intensities were undertaken using interactive programs developed by D. Mainprice of Université Montpellier II, France. Adolphe Nicolas, Shun-ichiro Karato, Greg Hirth, Aaron Stallard, and two anonymous reviewers provided valuable suggestions that helped to improve the paper. We acknowledge Tomoe Kuroda for her support and Aaron Stallard for improving the English of the manuscript. This study was supported by grants from the Japan Society for the Promotion of Science and NSF Grants OCE 9907063 and OCE 0002587. This paper is SOEST contribution XXXX and HIGP Contribution XXXX.

\section{References}

Ben Ismail, W. and Mainprice, D., 1998, An olivine fabric database: An overview of upper mantle fabrics and seismic anisotropy, Tectonophysics, 296, 145-157.

Bloomer, S. H., 1983. Distribution and origin of igneous rocks from the landward slopes of the Mariana Trench: Implications for its structure and evolution. Journal of Geophysical Res earch, 88, 7411-7428.

Dietrich, V., Emmermann, R., Oberhansli, R. and Puchelt, H., 1978. Geoch emistry of basaltic and gabbroic rocks from the west Mariana Trench. Earth and Planetary Science Letters, 39, 127-144.

Fischer, K. M., Fouch, M. J., Wiens, D. A. and Boettcher, M. S., 1998. Anisotropy and flow in Pacific subduction zone back-arcs. Pure Appl. Geophys., 151, 463-475.

Fryer, P., Becker, N., Appelgate, B., Martinez, F., Edwards, M. and Fryer, G, 2003. Why is the Challenger Deep so deep? Earth and Planetary Science Letters, 211, 259-269. 
244 Fryer, P., 1992. A synthesis of Leg 125 drilling of serpentine seamounts on the Mariana and 245 Izu-Bonin forearcs. In: Fryer, P., Pearce, J. A., Stokking, L. B. et al. eds. Proceedings of the 246 Ocean Drilling Program, Scientific Results, 125, pp. 593-614. College Station, TX, USA.

247 Fryer, P., Fujimoto, H., Sekime, M, Johnson, L. E., Kasahara, J., Masuda, H., Gamo, T., Ishii, 248 T., Ariyoshi, A. and Fujioka, K., 1998. Volcanoes of the southwestern extension of the 249 active Mariana island arc: New swath-mapping and geochemical studies. The Island Arc, 7, 250 596-607.

251 Fujioka, K., Okino, K., Kanamatsu, T. and Ohara, Y., 2002. Morphology and origin of the 252 Challenger Deep in the Southern Mariana Trench. Geophysical Research Letters, 29, $25310.1029 / 2001$ GL013595.

254 Gvirtzman, Z. and Stern, R. J., 2004. Bathymetry of Mariana Trench-arc system and 255 formation of the Challenger Deep as a consequence of weak plate coupling. Tectonics, 23, 256 TC2011, doi: 10.1029/2003TC001581.

257 Ishii, T., 1985. Dredged samples from the Ogasawara fore-arc seamount or 'Ogasawara 258 paleoland'-'Fore-arc ophiolite'. In: Nasu, N., Kobayashi, K., Uyeda, S., Kushiro, I. \& 259 Kagami, H. eds. Formation of Active Ocean Margins, pp. 307-42. Terra Scientific 260 Publishing Company, Tokyo.

261 Ishii, T., Robinson, P. T., Maekawa, H. and Fiske, R., 1992. Petrological studies of peridotites 262 from diapiric serpentinite seamounts in the Izu-Ogasawara-Mariana forearc, Leg 125. In: 263 Fryer, P., Pearce, J. A., Stokking, L. B. et al. eds. Proceedings of the Ocean Drilling 264 Program, Scientific Results, 125, pp. 593-614. College Station, TX, USA.

265 Ishii, T., Takemura, O., Igarashi, C., Ohara, Y. and Segawa, J., 1993. Description of dred ged 266 samples from Mariana forearc during the first leg (Tokyo to Guam) of KH92-1 cruise. In: 267 Segawa, J. ed. Preliminary Report of the Hakuho-Maru cruise KH92-1, pp. 109-129. Ocean 268 Research Institute, University of Tokyo, Tokyo, Japan.

269 Iwamori, H., 1998. Transportation of $\mathrm{H} 2 \mathrm{O}$ and melting in subduction zones. Earth Planet. Sci. 270 Lett., $160,65-80$.

271 Jung, H. and Karato, S., 2001. Water-induced fabric transitions in olivine. Science, 293, 272 1460-1463.

273 Jung, H., Katayama, I., Ziang, Z., Hiraga, T. and Karato, S., 2006. Effect of water and stress 274 on the lattice-preferred orientation of olivine. Tectonophysics, 421, 1-22.

275 Karig, D. E., 1971. Structural history of the Mariana island arc system, Geological Society of 276 America Bulletin, 82(2), 323-344. 
277 Katayama, I. and Karato, S., 2006. Effect of temperature on the B- to C-type olivine fabric 278 transition and implication for flow pattern in the subduction zone. Physics of the Earth and 279 Planetary Interior, 157, 33-45.

280 Katayama, I., Jung, H. and Karato, S., 2004. New type of olivine fabric from deformation 281 experiments at modest water content and low stress. Geology, 32, 1045-1048.

282 Michibayashi, K and Mainprice, D., 2004. The role of pre-existing mechanical anisotropy on 283 shear zone development within oceanic mantle lithosphere: an example from the Oman 284 ophiolite. Journal of Petrology, 45, 405-414.

285 Michibayashi, K., Gerbert-Gaillard, L. and Nicolas, A., 2000. Shear sense inversion in the 286 Hilti mantle section (Oman ophiolite) and active mantle uprise. Marine Geophysical 287 Researches, 21, 259-268.

288 Michibayashi, K., Ina, T. and Kanagawa, K, 2006a. The effect of dynamic recrystallization 289 on olivine fabric and seismic anisotropy: Insights from a ductile shear zone in the Oman 290 ophiolite. Earth and Planetary Science Letters, 244, 695-708.

291 Michibayashi, K., Abe, N., Okamoto A., Satsukawa, T. and Michikura, K., 2006b. Seismic 292 anisotropy in the uppermost mantle, back-arc region of the northeast Japan arc: 293 Petrophysical analyses of Ichinomegata peridotite xenoliths. Geophys. Res. Lett., 33, 294 L10312, doi:10.10029/2006GL025812.

295 Natland, J. H. \& Tarney, J., 1982. Petrologic evolution of the Mariana arc and back-arc basin 296 system: a systhes is of drilling results in the south Philippine Sea. In: Hussong, D. M., Uyeda, 297 S. et al. eds. Initial Reports of the Deep Sea Drilling Project, 60, pp. 877-908. US 298 Government Printing Office, Washington DC.

299 Nicolas, A, 1989. Structures in Ophiolites and Dynamics of Oceanic Lithosphere, Kluwer $300 \quad$ Academic Publishers, Dordrecht, 367 pp.

301 Nicolas, A. and Christensen, N. I., 1987. Formation of anisotropy in upper mantle peridotites 302 a review. In: Composition Structure and Dynamics of the Lithosphere-Asthenosphere 303 System K. Fuchs, C. Froidevaux, Eds. (AGU GM Ser, 1987), pp. 111-123.

304 Nicolas, A. and Poirier, J. P., 1976. Crystalline Plasticity and Solid Sate Flow in Metamorphic 305 Rocks. London, John Wiley, 444 pp.

306 Ohara, Y. and Ishii, T., 1998. Peridotites from the southern Mariana forearc: Heterogeneous 307 fluid supply in mantle wedge. The Island Arc, 7, 541-558. 
308 Figure captions

309

310 Figure 1. (A) Bathymetric map showing the location of dredge site KH92-1-D2 (11 $41.16^{\prime} \mathrm{N}$, 311 14329.62'E; depth 6594-7431 m), the southern Mariana Trench (solid barbed line), N-S 312 striking strike-slip faults that bound the Santa Rosa Bank (dashed lines west of GuamFryer et 313 al., 2003), the Challenger Deep, and the locations of the two cross-sections (after Gvirtzman 314 and Stern, 2004) shown in Fig. 1B. The dredge site is adjacent to the Challenger Deep, the 315 deepest site within the world's oceans. The unit used for the labeled bathymetric contours is $3161000 \mathrm{~m}$. (B) Schematic cross-sections across the southern Mariana Trench based on the 317 lithospheric sections inferred by Gvirtzman and Stern (2004). The asthenosphere propagates 318 toward the tip of the mantle wedge, reaching a point approximately $20 \mathrm{~km}$ below the sea floor 319 (Gvirtzman and Stern, 2004). The thinned lithosphere above the propagating asthenosphere in 320 the area close to the southern Mariana Trench is possibly intensely deformed under 321 low-temperature conditions (see the Discussion section).

322

323 Figure 2. Photomicrographs of microstructures within the analysed peridotite samples. The 324 scale bar in all images is $1 \mathrm{~mm}$, and all images were taken under crossed polarized light. (A) 325 Sample D2-23. Coarse $(\leq 5 \mathrm{~mm})$ equigranular texture. Locally intensely serpentinized and 326 carbonated. Grain boundaries in relatively fresh parts of the sample show triple junction 327 geometries. (B) Sample D2-13. Coarse (ca. $5 \mathrm{~mm}$ ) equigranular texture. Olivine grains show 328 moderate undulose extinction and have serrated grain boundaries. Grains are locally weakly 329 elongate in areas where grain-size reduction is evident (grain sizes reduced to $\leq 100 \mu \mathrm{m}$ ). 330 Numerous inclusions occur within olivine grains. (C) Sample D2-18. Coarse but intensely 331 elongate texture. Olivine grains are intensely elongated due to slip along cleavage planes. 332 Kinking or bending is recognized in olivine grains with patchy or undulose extinction. Rare 333 fine-grained $(\leq 100 \mu \mathrm{m})$ recrystallized grains occur along grain boundaries between highly 334 elongate grains. Grain boundaries are dominantly serpentinized. This texture resembles the 335 low-strain textures that are transitional from coarse granular texture to porphyroclastic texture 336 at the margin of a ductile shear zone described from the Oman Ophiolite (Michibay ashi and 337 Mainprice, 2004). (D) Sample D2-58. Coarse but intensely elongate texture. Coarse ( $\leq 5 \mathrm{~mm})$ 338 olivine grains are variably elongated up to aspect ratios of 5:1 due to slip along cleavage 339 planes. Parts of the sample exhibit equigranular textures, within which a narrow high-strain 340 zone occurs with very small (ca. $10 \mu \mathrm{m}$ ) recrystallized grains. Some grains contain numerous 
341 inclusions. (E) Sample D2-52. Porphyroclastic texture, although the microstructure is strongly 342 heterogeneous. Porphyroclasts are several millimeters in size and are locally elongated up to 343 aspect ratios of 3:1 due to slip along cleavage planes or kinking. Neoblasts vary in size from $344 \sim 10$ to $200 \mu \mathrm{m}$. Although the nature of the microstructure is obscured by serpentinization, 345 low-plasticity deformation such as kinking appears to be the mechanism behind the observed 346 grain-size reduction. (F) Sample D2-110. Relatively homogeneous fine-grained $(<1 \mathrm{~mm})$ 347 equigranular texture. Olivine grains show triple junction boundaries. Locally, relict 348 porphyroclasts possess irregular shapes.

349

350 Figure 3. Pole figures for the crystallographic axes of olivine grains. All plots are equal area, 351 lower hemisphere projections in the structural (XZ) reference frame, with the foliation 352 oriented vertically east-west and the lineation being horizontal. (A) Sample D2-23; possibly a 353 (010)[100] pattern. (B) Sample D2-13; (010)[001] pattern. (C) Sample D2-18; (010)[100] 354 pattern. (D) Sample D2-58; (010)[001] pattern. (E) Sample D2-52; olivine CPO is weak, with 355 a maxima of (001) normal to the foliation. (F) Sample D2-110; olivine CPO is very weak. 


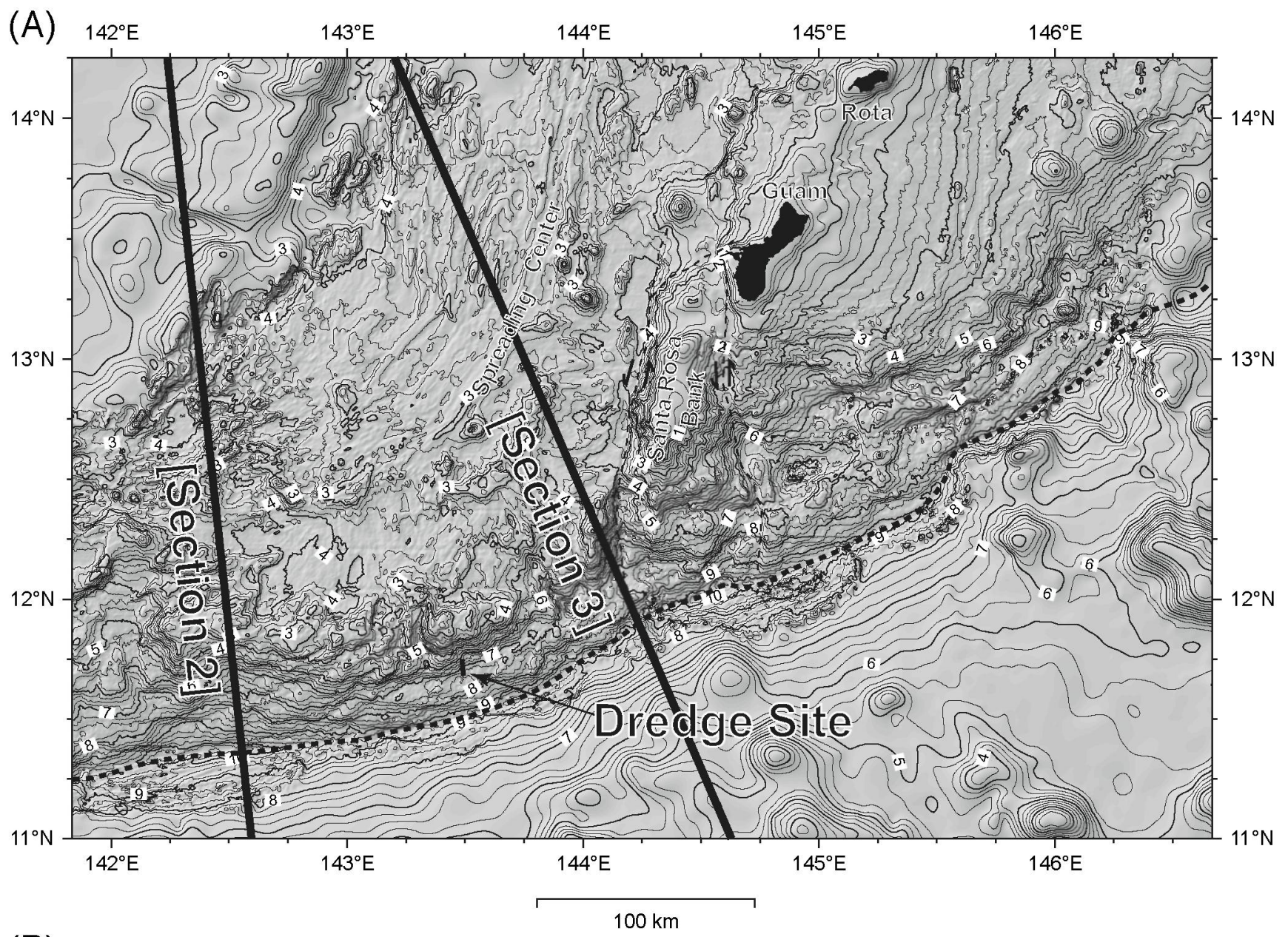

(B)
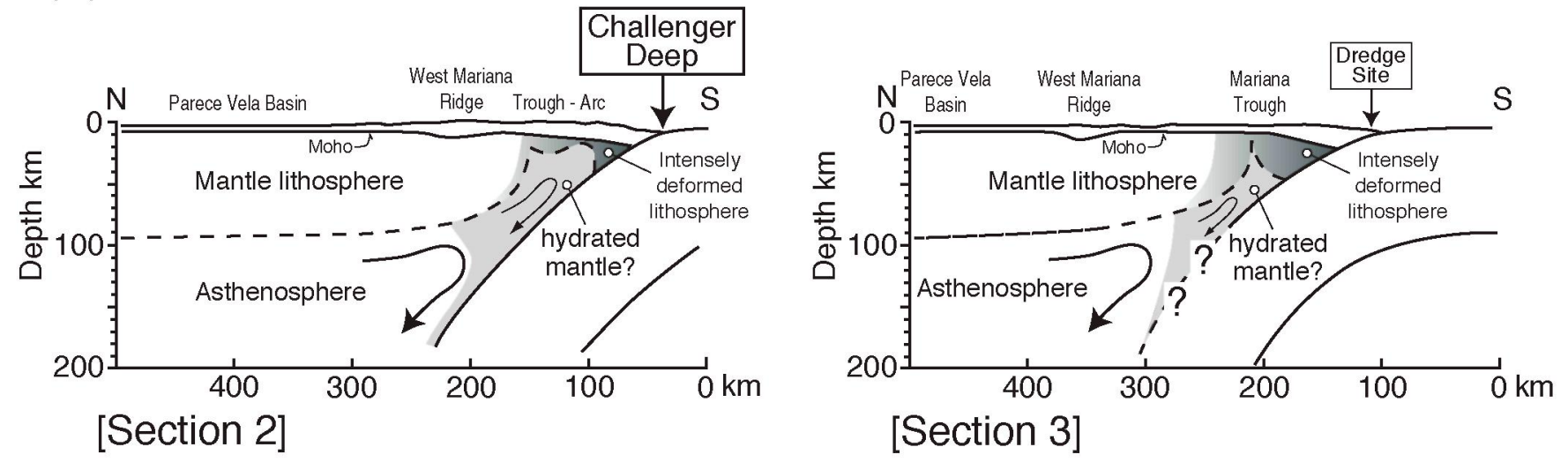

Figure 1: Michibayashi et al. 

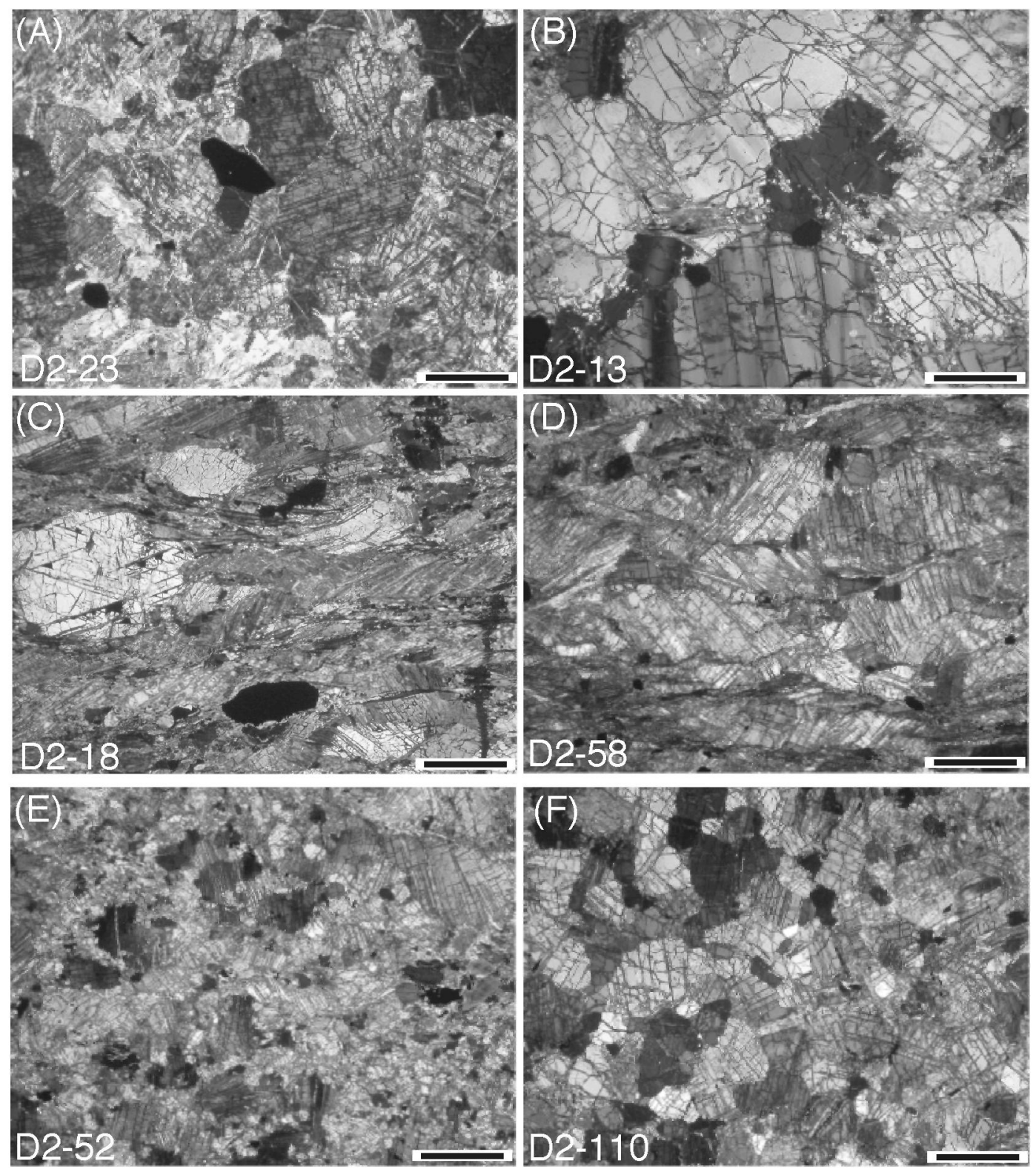

Figure 2: Michibayashi et al. 

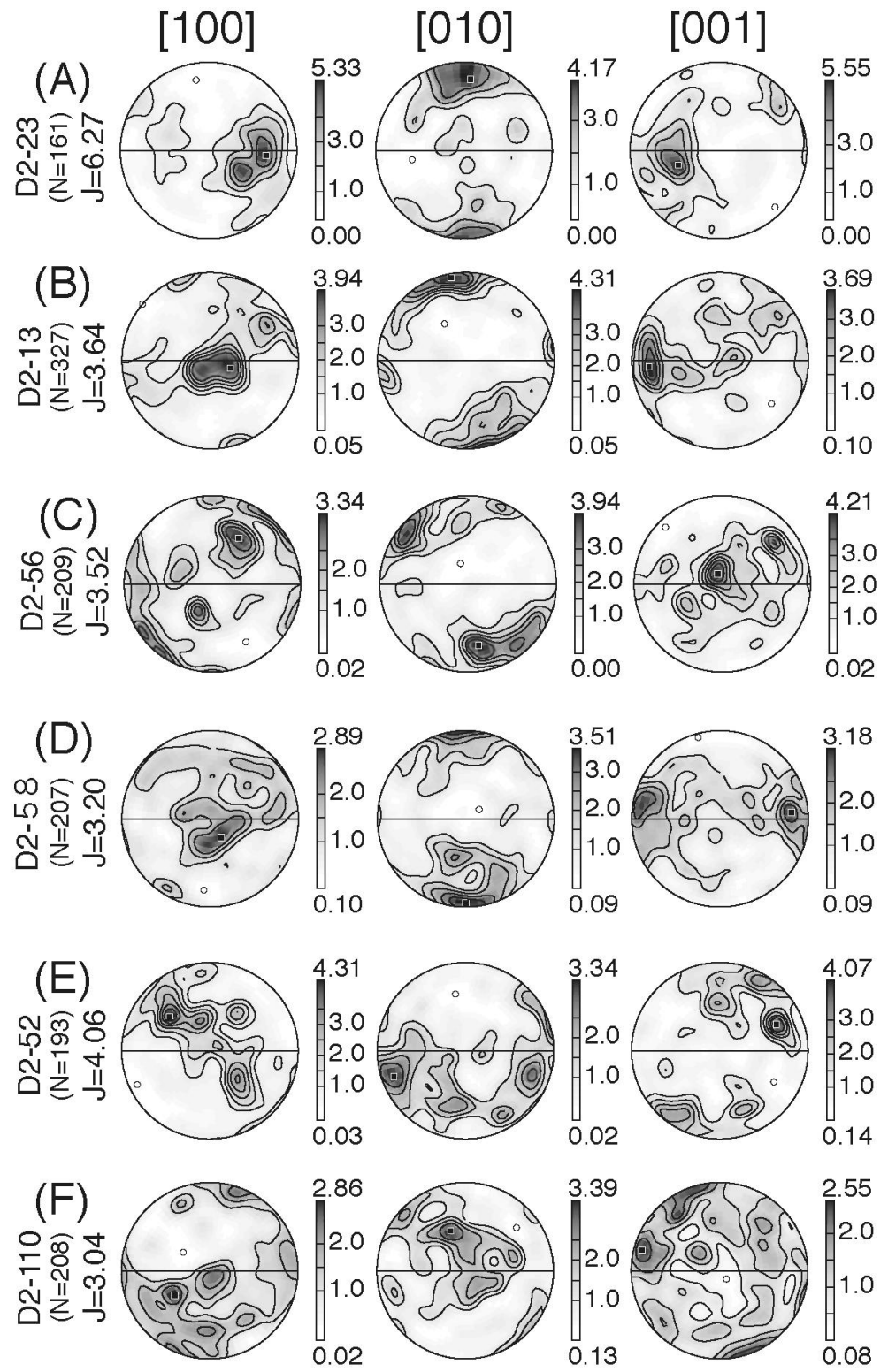

Figure 3: Michibayashi et al. 